\title{
Plasma and Erythrocyte Phospholipid Fatty Acids Composition in Serbian Hemodialyzed Patients
}

Vanja Ristić, Vesna Tepšić, Danijela Ristić-Medić, Gordana Peruničić, Zorica Rašić, Marija Poštić, Aleksandra Arsić, Vera Blaženčić-Mladenović \& Gordana Ristić

To cite this article: Vanja Ristić, Vesna Tepšić, Danijela Ristić-Medić, Gordana Peruničić, Zorica Rašić, Marija Poštić, Aleksandra Arsić, Vera Blaženčić-Mladenović \& Gordana Ristić (2006) Plasma and Erythrocyte Phospholipid Fatty Acids Composition in Serbian Hemodialyzed Patients, Renal Failure, 28:3, 211-216, DOI: 10.1080/08860220600574897

To link to this article: https://doi.org/10.1080/08860220600574897

曲 Published online: 07 Jul 2009.

Submit your article to this journal $\pi$

山 Article views: 323

Q View related articles 5

Citing articles: 3 View citing articles $๘$ 


\title{
CLINICAL STUDY
}

\section{Plasma and Erythrocyte Phospholipid Fatty Acids Composition in Serbian Hemodialyzed Patients}

\author{
Vanja Ristić, Ph.D., Vesna Tepšić, M.D., M.Sc., and Danijela Ristić-Medić, M.D., M.Sc. \\ Institute for Medical Research, Laboratory for Nutrition and Metabolism, Belgrade, Serbia and Montenegro
}

Gordana Peruničić, M.D., Ph.D. and Zorica Rašić, M.D., Ph.D.

Department of Nephrology, University Hospital Zemun, Belgrade, Serbia and Montenegro

\author{
Marija Poštić, B.Sc., Aleksandra Arsić, B.Sc., Vera Blaženčić-Mladenović, M.D., M.Sc., and \\ Gordana Ristić, Ph.D. \\ Institute for Medical Research, Laboratory for Nutrition and Metabolism, Belgrade, Serbia and Montenegro
}

\begin{abstract}
Dyslipidemia is one of the possible risk factors for advanced atherosclerosis in patients with chronic renal failure. Abnormal phospholipid metabolism may play an important role in the progression of atherosclerosis in patients with renal failure. The aim of this study was to determine specific characteristics of plasma and erythrocyte phospholipid content and fatty acid composition in 37 patients with chronic renal failure on hemodialysis (HD). The results were compared with the characteristics of healthy subjects. Briefly, plasma triglyceride $(p<0.001)$, total cholesterol $(p<0.05)$, and total phospholipids $(p<0.01)$ levels were significantly higher and HDL-cholesterol level significantly lower $(p<0.01)$ in HD patients. Plasma phosphatidylcholine and phosphatidylethanolamine concentration were significantly higher $(p<0.001)$ in HD patients. The plasma phospholipid fatty acids composition indicated significantly $(p<0.01)$ higher level of oleic $(18: 1 \mathrm{n}-9)$ and lower levels of eicopentaenoic (20:5 n-3 EPA) and docosahexaenoic (22:6 n-3 DHA) acids $(p<0.05)$. However, in HD patients, the relative concentration of plasma phospholipid n-6 polyunsaturated fatty acid (PUFA) was significantly lower $(p<0.05)$. The fatty acid composition of erythrocyte phospholipid in HD patients was modified with EPA and DHA levels significantly lowered $(p<0.05)$. Our results demonstrate an abnormal
\end{abstract}

Address correspondence to Danijela Ristić-Medić, M.D., M.Sc., Institute for Medical Research, Laboratory for Nutrition and Metabolism, 11129 Belgrade, P.O. Box 102, Serbia and Montenegro; Fax: +381 11 643691; E-mail: danijelar@imi.bg.ac.yu gordanar2000@yahoo.com phospholipid metabolism and deficiency of n-3 PUFA in plasma and erythrocyte phospholipids in hemodialyzed patients.

Keywords lipids, phospholipids, fatty acids, plasma, erythrocyte, hemodialysis

\section{INTRODUCTION}

Several abnormalities of lipid metabolism occur in patients with chronic renal failure. ${ }^{[1,2]}$ In these patients, dyslipidemia is a characteristic feature and has been implicated in the pathogenesis of cardiovascular complications. ${ }^{[3,4]}$ Compared with the general population, those with end-stage renal disease have a substantially elevated risk of death from cardiovascular disease. Statistics show that $50-60 \%$ of all deaths among dialysis patients are secondary to cardiovascular complication. ${ }^{[5]}$ The most common plasma lipid abnormalities in patients with chronic renal failure on hemodialysis are high triglycerides, small LDL particles, and low HDL-cholesterol. ${ }^{[6,7]}$ The lipoprotein abnormalities and hemodialysis appear to be the result of impaired lipoprotein catabolism. A number of investigations have shown that the activities of lipoprotein lipase, hepatic triglyceride lipase, and lecithin cholesterol acyltransferase (LCAT) are reduced in chronic renal failure. ${ }^{[2]}$ LCAT deficiency is common in uremia and is associated with changes not just in plasma lipids but also in membrane lipids, which may be relevant to the progression of chronic renal disease. ${ }^{[8]}$ 
Phospholipids play an essential role in membrane structure and function. The length and degree of unsaturated membrane phospholipids fatty acids are main determinants of fluidity, transport systems, activity of membrane-bound enzymes, and susceptibility to lipid peroxidation. ${ }^{[9-11]}$ The fatty acid profile of serum lipid, especially the phospholipids, reflects the fatty acid composition of cell membranes. ${ }^{[12]}$ There are limited and inconclusive data, which deal with changes in fatty acid metabolism and in fatty acid composition of plasma phospholipids in chronic renal failure. ${ }^{[13-15]}$ Erythrocytes can alter phospholipids fatty acids composition only by the exchange of intact molecules with plasma lipids but cannot alter fatty acid chain length or the degree of unsaturation. It has been established that erythrocytes reflect the general fatty acid metabolism in other organs and tissues. ${ }^{[16,17]}$ The aim of this study was to determine specific characteristics of plasma and erythrocyte phospholipids content and fatty acid composition in patients with chronic renal failure on hemodialysis.

\section{METHODS}

\section{Patients}

The study was carried out in 37 chronic renal failure patients from the Department of Nephrology, University Hospital Zemun, Belgrade. All patients (21 male, 16 female, mean age $52 \pm 10$ years, range 42-64) had been on maintenance hemodialysis three times a week. The patients were clinically stable, with adequate nutrition/inflammatory status and with no recorded cardiovascular events (coronary heart disease and cerebrovascular disease). The mean body mass index (BMI) calculated from dry body weight was $23.65 \pm 3.52 \mathrm{~kg} / \mathrm{m}^{2}$ (range 19.8-27.3). Serum albumin concentration was $41.1 \pm 2.9 \mathrm{~g} / \mathrm{L}$ and serum C-reactive protein level was $3.08 \pm 1.48 \mathrm{mg} / \mathrm{mL}$. Patients' characteristics and their primary renal disease are shown on Table 1.

Patients with a history of nephrotic syndrome, diabetes mellitus, alcohol consummation, systemic illness, or any other disease that might influence lipid metabolism were excluded. None of the patients received lipid lowering drugs, L-carnitine or $\beta$-blockers in the 3 months prior to entering the study. However, 25 patients with hypertension received treatment angiotensin-converting enzyme inhibitors. Patients received no other medications except multivitamins, calcitriol phosphate binders, and/or iron. Patients maintained their habitual diets $(35 \mathrm{kcal} / \mathrm{kgbw}$, protein intake $1-1.2 \mathrm{~g} / \mathrm{kgbw}$, fats $<35 \%$ caloric intake) with sodium and potassium restriction during the previous 3 months. They had low habitual consumption of foods
Table 1

Patients' characteristics

\begin{tabular}{lc}
\hline No. $(\mathrm{M} / \mathrm{F})$ & $37(21 / 16)$ \\
Age (years) & $52 \pm 10$ \\
Duration (years) & $6 \pm 3$ \\
BMI $\left(\mathrm{kg} / \mathrm{m}^{2}\right)$ & $23.65 \pm 3.52$ \\
Hypertension (yes/no) & $25 / 12$ \\
Primary causes of end-stage renal disease $(\%)$ & \\
$\quad$ Glomerulonephritis & $11(30)$ \\
Pyelonephritis & $11(30)$ \\
Polycystic kidney disease & $7(19)$ \\
Nephropathies endemic & $6(16)$ \\
Nephroangiosclerosis & $2(5)$ \\
\hline
\end{tabular}

containing soy, fish intake once a week, and no dietary supplementation of oil rich in long-chain fatty acid (fish, sesame, or linseed oil) as determined by diet assessment made at the time of recruitment. Blood samples were drowning from their fistula before dialysis and after a 12to 14-h overnight fast. Blood samples were collected from 29 healthy volunteers (control group) from medical staff and blood donors (17 males, 12 females, mean age $55 \pm 9$ years, range 44-62) after a 12-h overnight fast. All patients signed an informed consent document. Study protocol was approved by the Medical Ethics Committee (Institute for Medical Research, Belgrade) and conducted in line with the principles of good scientific practice.

\section{Biochemical Determination}

Serum samples were prepared by $4^{\circ} \mathrm{C}$ centrifugation of venous blood collected after $12-$ to 14 -h fast. Total serum cholesterol and triglyceride level were measured spectrophotometrically by using a colorimetric enzymatic reaction (EliTech Diagnostic, Sées, France). Serum albumin concentration was determined by using bromcresolgreen reagent (EliTech Diagnostic). HDL-cholesterol was determined by measuring the cholesterol in supernatant liquid after serum precipitation with phosphotungstic acid, magnesium chloride, and LDL-cholesterol was estimated by using Friedewald formula. ${ }^{[18,19]}$ Total phospholipids were determined by the method of Zilversmit and Davis. ${ }^{[20]}$ C-reactive protein (CPR) level was measured with a ELISA test (EliTech Diagnostic), with rabbit antibodies to human CRP. Values $<6 \mathrm{mg} / \mathrm{L}$ were considered normal.

Plasma lipids were extracted with chloroformmethanol mixture (2:1 v/v) by Sperry and Brand method. ${ }^{[21]}$ Plasma phospholipids were separated by thin-layer chromatography (TLC) into four fractions [i.e., lysophosphatidylcholine (LPC), phosphatidylcholine (PC), sphingophospholipids (SPL), and phosphatidylethanolamine 
(PE)] in a one-dimensional TLC system using chloroform:methanol:20\% ammonia solution $(70: 25: 5, \mathrm{v} / \mathrm{v} / \mathrm{v})$ as the eluting solvent.

After removing the plasma and buff coat, packed erythrocytes $(2-3 \mathrm{~g})$ were washed three times with $5 \mathrm{~mL}$ of $0.9 \%$ $\mathrm{NaCl}$ and separated by centrifugation (3000 r.p.m. for $10 \mathrm{~min}$ ) before homogenization. The washing solution was discarded, and the global fraction was frozen at $-20^{\circ} \mathrm{C}$ for $1 \mathrm{~h}$ to produce rupture of the erythrocyte membrane. Red blood cell membrane lipids were extracted by Harth's method. ${ }^{[22]}$ The phospholipid fraction was isolated from the extracted lipids by one-dimensional TLC in a neutral solvent system hexane-diethyl ether-acetic acid (87:12:1 v/v) using Silica Gel GF plates (C. Merck, Darmstadt, Germany).

Methyl esters of phospholipid fatty acids (from plasma and erythrocytes) were preparated by methods reported previously. ${ }^{[23]}$ Fatty acid methyl esters derivatives formed from isolated plasma phospholipid fraction were separated by gas chromatography using a Varian GC (model 3400, Varian Associates) as described. ${ }^{[2]}$ Individual fatty acid methyl esters in the sample were identified from the retention times of authentic standards (Sigma Chemical Co) and/ or polyunsaturated fatty acids (PUFA-2) mixture (Supelco Inc., Bellefonte). Peak areas were determined with a Varian 4290 integrator, and the results were expressed as the relative percentage of total identified fatty acids.

\section{Statistical Analyses}

All results are expressed as means $\pm \mathrm{SD}$. The data were analyzed by using one-way analysis of variance model followed by The Fisher exact test, ${ }^{[25]}$ accepting an alpha level of significance 0.05 .

\section{RESULTS}

Plasma lipids' profile of $37 \mathrm{HD}$ patients is shown on Table 2. Plasma triglyceride $(p<0.001)$, total cholesterol $(p<0.05)$, and total phospholipids $(p<0.01)$ levels were significantly higher, and HDL-cholesterol levels significantly lower $(p<0.01)$ in HD patients than in the control subjects. Plasma PC and PE concentrations were significantly higher $(p<0.001)$ in HD patients. LDL-cholesterol was not different in plasma of HD patients. Plasma phospholipids distribution (Table 3 ) showed significantly higher $(p<0.001)$ participation of PC and lower $(p<0.001)$ participation of LPC, SPL, and PE $(p<0.01)$ in HD patients

Plasma and erythrocyte phospholipid fatty acids composition in HD patients is shown in Table 4. These results indicate no difference in plasma phospholipid saturated fatty acids, significantly higher $(p<0.01)$ level of oleic
Table 2

Plasma lipids profile

\begin{tabular}{llc}
\hline $\begin{array}{l}\text { Plasma lipids } \\
(\mathrm{mmol} / \mathrm{L})\end{array}$ & $\begin{array}{c}\text { Hemodialysis } \\
\text { patients }(n=37)\end{array}$ & $\begin{array}{c}\text { Control subjects } \\
(n=29)\end{array}$ \\
\hline Triglycerides & $2.30 \pm 0.29 * * *$ & $1.38 \pm 0.26$ \\
Total cholesterol & $5.48 \pm 0.89^{*}$ & $5.00 \pm 0.64$ \\
HDL-cholesterol & $1.42 \pm 0.44^{* *}$ & $1.69 \pm 0.33$ \\
LDL-cholesterol & $3.04 \pm 0.81$ & $3.13 \pm 0.60$ \\
Total phospholipids & $3.10 \pm 0.66^{* * *}$ & $2.25 \pm 0.35$ \\
Phosphatidylcholine & $2.16 \pm 0.10^{* * *}$ & $1.45 \pm 0.06$ \\
Lysophosphatidylcholine & $0.21 \pm 0.03$ & $0.21 \pm 0.02$ \\
Sphingophospholipids & $0.57 \pm 0.04$ & $0.46 \pm 0.02$ \\
Phosphatidylethanolamine & $0.15 \pm 0.02 * * *$ & $0.12 \pm 0.01$ \\
\hline
\end{tabular}

The values are means \pm SD.

*Significantly different compared to C group, $p<0.05$.

**Significantly different compared to $\mathrm{C}$ group, $p<0.01$.

$* * *$ Significantly different compared to $\mathrm{C}$ group, $p<0.001$.

Table 3

Plasma phospholipids distribution

\begin{tabular}{lcr}
\hline Phospholipids (\%) & $\begin{array}{c}\text { Hemodialysis } \\
\text { patients }(n=37)\end{array}$ & $\begin{array}{c}\text { Control subjects } \\
(n=29)\end{array}$ \\
\hline Phosphatidylcholine & $69.60 \pm 3.14 * * *$ & $64.40 \pm 2.82$ \\
Lysophosphatidylcholine & $6.96 \pm 0.86^{* * *}$ & $9.41 \pm 0.82$ \\
Sphingophospholipids & $18.45 \pm 1.38^{* * *}$ & $20.70 \pm 0.99$ \\
Phosphatidylethanolamine & $4.99 \pm 0.82 * *$ & $5.49 \pm 0.38$ \\
\hline
\end{tabular}

The values are means \pm SD.

*Significantly different compared to C group, $p<0.05$.

$* *$ Significantly different compared to $\mathrm{C}$ group, $p<0.01$.

$* * *$ Significantly different compared to $\mathrm{C}$ group, $p<0.001$.

(18:1 n-9), and significantly lower $(p<0.05)$ levels of eicopentaenoic (20:5 n-3 EPA) and docosahexaenoic (22:6 n-3 DHA) acids in HD patients. MUFA (monounsaturated fatty acids) was significantly higher $(p<0.05)$, and PUFA $\mathrm{n}-3$ significantly lower $(p<0.05)$ than in the control subjects. In HD patients, PUFA n-6 was significantly lower $(p<0.05)$. However, the fatty acid composition of erythrocyte phospholipid in HD patients was also altered (Table 4). EPA and DHA levels were significantly lower $(p<0.05)$, and consistent with this, PUFA n-3 levels were significantly lower $(p<0.05)$ than in control subjects.

\section{DISCUSSION}

Dyslipidemia is one of the main risk factors of cardiovascular complications in patients with chronic renal disease ${ }^{[3,4]}$ There is increasing evidence that hyperlipidemia is a contributing factor to the progression of chronic renal 
Table 4

Plasma and erythrocyte phospholipid fatty acids composition (mol\%) in hemodialysis patients

\begin{tabular}{|c|c|c|c|c|}
\hline \multirow[b]{2}{*}{ Fatty Acids } & \multicolumn{2}{|c|}{ Plasma phospholipids } & \multicolumn{2}{|c|}{ Erythrocyte phospholipids } \\
\hline & HD patients $(n=37)$ & Controls $(n=29)$ & HD patients $(n=37)$ & Controls $(n=29)$ \\
\hline $16: 0$ & $28.09 \pm 3.34$ & $26.46 \pm 2.44$ & $21.63 \pm 1.85$ & $22.42 \pm 2.59$ \\
\hline 18:0 & $15.67 \pm 3.59$ & $16.14 \pm 2.41$ & $19.28 \pm 1.49$ & $18.71 \pm 1.71$ \\
\hline $16: 1 \mathrm{n}-7$ & $0.41 \pm 0.26$ & $0.29 \pm 0.16$ & - & - \\
\hline $18: 1 \mathrm{n}-9$ & $13.05 \pm 2.21 * *$ & $11.71 \pm 1.24$ & $17.86 \pm 1.77$ & $17.53 \pm 2.70$ \\
\hline $18: 2 n-6$ & $25.50 \pm 2.88$ & $26.47 \pm 2.78$ & $14.80 \pm 2.01$ & $15.53 \pm 1.83$ \\
\hline $20: 3 n-6$ & $1.98 \pm 0.50$ & $2.42 \pm 0.71$ & $1.26 \pm 0.41$ & $1.24 \pm 0.44$ \\
\hline $20: 4 n-6$ & $11.06 \pm 2.21$ & $11.56 \pm 2.32$ & $15.29 \pm 1.83$ & $16.25 \pm 2.03$ \\
\hline $22: 4 n-6$ & $0.44 \pm 0.11$ & $0.39 \pm 0.19$ & $3.54 \pm 0.86$ & $3.53 \pm 1.23$ \\
\hline $20: 5 n-3$ & $0.26 \pm 0.14 *$ & $0.36 \pm 0.14$ & $0.23 \pm 0.06^{*}$ & $0.49 \pm 0.14$ \\
\hline $22: 5 n-3$ & $0.54 \pm 0.14$ & $0.57 \pm 0.10$ & $1.21 \pm 0.40$ & $1.29 \pm 0.46$ \\
\hline $22: 6 n-3$ & $3.00 \pm 0.90 *$ & $3.63 \pm 1.12$ & $4.33 \pm 0.83^{*}$ & $5.32 \pm 1.10$ \\
\hline SFA & $43.77 \pm 5.23$ & $42.60 \pm 3.10$ & $40.91 \pm 2.97$ & $41.13 \pm 4.84$ \\
\hline MUFA & $13.45 \pm 2.50^{*}$ & $12.00 \pm 1.74$ & $17.86 \pm 1.77$ & $17.53 \pm 2.70$ \\
\hline PUFA n-6 & $38.98 \pm 3.28 *$ & $40.84 \pm 2.86$ & $34.87 \pm 3.50$ & $36.59 \pm 2.39$ \\
\hline PUFA n-3 & $3.80 \pm 1.19 *$ & $4.56 \pm 1.35$ & $5.96 \pm 0.88^{*}$ & $6.93 \pm 1.27$ \\
\hline$n-6 / n-3$ & $9.59 \pm 1.32$ & $8.82 \pm 1.58$ & $5.93 \pm 0.91$ & $5.46 \pm 1.06$ \\
\hline
\end{tabular}

The values are means \pm SD.

*Significantly different compared to $\mathrm{C}$ group, $p<0.05$.

**Significantly different compared to $\mathrm{C}$ group, $p<0.01$.

diseases. ${ }^{[1,26]}$ In our study, patients on hemodialysis have higher levels of plasma triglycerides, total cholesterol, and lower levels of HDL-cholesterol. Even though low HDL-cholesterol levels are always associated with hypertriglyceridemia, ${ }^{[27]}$ it is reasonable to argue that low HDL-cholesterol is strictly linked to the changes in triglyceride metabolism.

Abnormal phospholipid metabolism may play an important role in the progression of atherosclerosis in patients with end-stage renal disease. ${ }^{[28,29]}$ Plasma phospholipids distribution was altered in HD patients in our study. In the present data, we have found a significant decrease in plasma SPL distribution in HD patients. The in vitro study by Zager ${ }^{[30]}$ showed that SPL could directly decrease cell/membrane damage. In fact, Zager argued that SPL could extend potent antiproliferative effects in the setting of subendotel tubular damage in renal failure. SPL serves as a critical modulator of membrane fluidity. ${ }^{[31]}$ The importance of phospholipids for the structure and integrity of cellular membranes suggests that many functional disturbances in renal failure may be related to changes in phospholipids distribution and fatty acid composition. In our study, disturbance in fatty acid metabolism in HD is evident. The level of oleic acid (one of MUFA) in plasma phospholipids was elevated, and the levels of PUFA, especially EPA and DHA, two n-3 PUFA, was reduced in plasma and erythrocyte phospholipids. Our results showing the increase of oleic acid and total MUFA in patients with chronic renal failure agree with previous reports. ${ }^{[32,33]}$ De Gomez Dumm et al. ${ }^{[32]}$ found decreased plasma PUFA in patients on hemodialysis; the lipid composition abnormality persisted after 18 months and became more notorious after 30 months. Varga et al. ${ }^{[33]}$ concluded that the relative abundance of saturated fatty acids (SFA) and MUFA in plasma of HD patients is associated with concomitant lipid disorders and cardiomyopathy, whereas the low relative abundance of PUFA was common in all HD patients. Conversely, Reaven et al. ${ }^{[34]}$ reported that the high oleic acid content in patients with chronic renal failure might exhibit protective roles.

Studies examining the relationship between blood individual fatty acid with serum triglycerides and total cholesterol are not consistent. ${ }^{[35,36]}$ Grimsgarard et al. ${ }^{[37]}$ reported that the concentration of EPA and DHA and total n-3 showed inverse association with serum triglycerides, whereas oleic acid was positively associated with triglyceride concentrations. Plasma triglyceride concentration represents a functional indicator of n-3 PUFA because n-3 PUFA exerts a consistent hypertriglyceridemic effect, which is dose dependent and persistent. ${ }^{[38]}$ Decrease in PUFA, especially n-3 may be a risk factor for depression often present in patients on hemodialysis. ${ }^{[39]}$ Disturbances in fatty acid metabolism in HD patients in our study (increased oleic acid, decreased EPA and DHA) are associated with high triglyceride levels. Our results showed abnormal lipid metabolism (triglycerides and phospholipids) 
and deficiency of n-3 PUFA that may indicate the risk and/or progression of atherosclerosis. In addition, published data ${ }^{[40]}$ suggested that a high proportion of $n-3$ PUFA in red blood cell membranes is associated with a reduced risk of primary cardiac arrest.

In our study, PUFA n-3 (EPA and DHA) decreased in erythrocyte phospholipids (PUFA n-6 also decreased but not significantly) and may be connected with lower membrane fluidity in patients with chronic renal failure. ${ }^{[41]}$ This is because the length and degree of unsaturation of the membrane phospholipid fatty acid are the main determinants of fluidity. ${ }^{[42]}$ Peuchant et al. ${ }^{[43]}$ found that erythrocytes of patients with chronically renal failure showed increased lipid peroxidation associated with a reduction in long-chain PUFA. Abnormal fatty acid metabolism may contribute to clinical problems such as itching, pruritus, abnormal perspiration, susceptibility to infection, delayed wound healing, anemia, and increased hemolysis, ${ }^{[15,38]}$ as seen in patients on hemodialysis.

Being overweight and hyperlipidemia are established risk factors in the general population, whereas lower body mass index and lower plasma cholesterol have been shown to be risk factors for cardiovascular mortality in end-stage renal disease. ${ }^{[39,44]}$ Long-term therapy and inadequate diet regimen in end-stage renal disease (terminal phase) lead to weight loss. Dialysis procedure may accentuate malnutrition by removing important nutrients. In addition, malnutrition is characterized by not only impaired lipid metabolism but also results in modification of plasma and erythrocyte fatty acid profile. It is interesting that the studied patients on HD who have adequate nutrition status also show a deficit of essential PUFA, particularly n-3 PUFA. Because composition of fatty acids of serum and erythrocyte phospholipids clearly reflects dietary habits, ${ }^{[45]}$ we suggest that more attention be given to the content and composition of dietary fat to prevent distribution in fatty acid metabolism in all patients with end-stage renal disease and not only in malnutrition ones.

In summary, plasma phospholipids fatty acid profile in our patients on hemodialysis indicate the necessity of nutrition care programs and the use of appropriate diet with adequate n-6/n-3 fatty acid ratio. Well-designed and controlled studies are needed to determine if supplementation might lead to prevention or regression of atherosclerosis and could remove some clinical problems in hemodialyzed patients.

\section{ACKNOWLEDGMENT}

This research was supported by a grant from the Serbian Ministry of Science and Environmental Protection No. 145071, Serbia and Montenegro.

\section{REFERENCES}

1. Chan MK. Lipid abnormalities in renal failure: Clin Biochem. 1990;23:61-65.

2. Attman P, Samuelsson O, Alaupović P. Lipoprotein metabolism and renal failure. Am J Kidney Dis. 1993; 21:573-592.

3. Mittman N, Avram MM. Dyslipidemia in renal disease. Semin Nephrol. 1996;16:202-213.

4. Ritz E. Why are lipids predictive of cardiovascular death in the dialysis patient? Miner Electrolyte Metab. 1996;22:9-12.

5. Owen WF, Madore F, Brenner BM. An observational study of cardiovascular characteristics of long-term end-stage renal disease survivors. Am J Kidney Dis. 1996;28:931-936.

6. Norbeck HE, Carlson LA. The uremic dyslipoproteinemia: its characteristics and relations to clinical factors. Acta Med Scand. 1981;209:489-503.

7. Bergesio F, Monzani G, Ciuti R, Serruto A, Benucci A, Frizzi V, Salvadori M. Lipids and apolipoproteins change during the progression of chronic renal failure. Clin Nephrol. 1992;38:264-270.

8. Gilett MP, Obineche EN, El-Rkhaimi M, Lakhani MS, Abdulle A, Sulaiman M. Lecithin: cholesterol acyltransferase, dyslipoproteinemia and membrane lipids in uraemia. J Nephrol. 2001;14(6):472-480.

9. Stubbs CD, Smith AD. The modification of mammalian membrane polyunsaturated fatty acid composition in relation to membrane fluidity and function. Biochem Biophys Acta. 1984;779:89-137.

10. Spector AA, Yorek MA. Membrane lipid composition and cellular function. J Lipid Res. 1985;26:1015-1035.

11. Clemens MR, Ruess M, Bursa Z, Dierck Waller H. The relationship between lipid composition of red blood cells and their susceptibility to lipid peroxidation. Free Rad Red Commun. 1987;3:265-271.

12. Dougherty RM, Galli G, Ferro-Luzzi A, Iacono JM. Lipid and phospholipid fatty acid composition of plasma, red blood cells, and platelets and how they are affected by dietary lipids: study of normal subjects from Italy, Finland and USA. Am J Clin Nutr. 1987;45:443-455.

13. Wanner C, Krane V, Metzger T, Quaschning T. Lipid changes and statins in chronic renal insufficiency and dialysis. J Nephrol. 2001;14(Suppl 4):S76-S80.

14. Ahmad S, Dasgupta A, Kenny MA. Fatty acid abnormalities in hemodialysis patients: effect of L-carnitine administration. Kidney Int. 1989;36(Suppl):S243-S246.

15. Peck LW. Essential fatty acid deficiency in renal failure: can supplements really help? J Am Diet Assoc. 1997;97(Suppl 2):S150-S153.

16. Shohet SB, Nathan DG. Incorporation of phosphatide precursors from serum into erythrocytes. Biochim Biophys Acta. 1970;202:202-205.

17. Mulder E, Van Deenen LM. Metabolism of red-cell lipids: pathways for phospholipids renewal. Biochim Biophys Acta. 1965;106:348-356.

18. Lopes-Virela MF, Stone P, Ellis S, Colwell JA. Cholesterol determination in high-density lipoproteins 
separated by three different methods. Clin Chem. 1977;23:882-884.

19. Friedewald WT, Levy RI, Friedrickson DS. Estimation of the concentration of low density lipoprotein cholesterol in plasma without use of the ultracentrifuge. Clin Chem. 1972;18:449-502.

20. Zilversmit DB, Davis AK. Microdetermination of plasma phospholipids by trichloroacetic acid precipitation. J Lab Clin Med. 1950;35:155-160.

21. Matusik EJ, Reeves VB, Flanagan VP. Determination of fatty acid methyl esters. Anal Chimi Acta. 1984;166:179-188.

22. Harth S, Dreyfus H, Urban PF, Mandel P. Direct thin-layer chromatography of gangliosides of total lipid extracts. Anal Biochem. 1978;86:543-551.

23. Ristić V, Vrbaški SR. Effect of diazepam on the fatty acid composition of plasma and liver phospholipids in rat. Biochem Med Metab Biol. 1992;47:19-24.

24. Ristić V, Vrbaški SR, Lalić Ž, Mirić M. The effect of ethanol and diazepam on the fatty acid composition of plasma and liver phospholipids in the rat. Biol Pharm Bull. 1995; 18:842-845.

25. Fisher RA. Statistical Methods for Research Workers. Oliver and Boyd: Edinburgh, 1970.

26. Oda H, Keane WF. Lipids in progression of renal disease. Kidney Int. 1997;52(Suppl 62):36-38.

27. Steele J, Billington T, Janus E, Moran J. Lipids, lipoproteins and apolipoproteins A-1 and B and apolipoprotein losses in continuous ambulatory peritoneal dialysis. Atherosclerosis. 1989;79:47-50.

28. Sasagawa T, Suzuki K, Shiota T, Kondo T, Okita M. The significance of plasma lysophospholipid in patients with renal failure on hemodialysis. J Nutr Sci Vitaminol (Tokyo). 1998;44:809-818.

29. Norbeck HE, Wallidius S. Fatty acid composition of serum and adipose tissue lipids in males with chronic renal failure. Acta Med Scand. 1982;211:75-85.

30. Zager RA. Sphingomyelinase and membrane sphingomyelin content: determinants of proximal tubule cell susceptibility to injury. J Am Soc Pephrol. 2000;11:894-902.

31. Barenholz Y, Thompson TE. Sphingomyelins in bilayers and biological membranes. Biochim Biophys Acta. 1980; 604:129-158.

32. De Gomez Dumm NT, Giammona AM, Touceda LA, Raimondi A. Lipid abnormalities in chronic renal failure patients undergoing hemodialysis. Medicina (B Aires). 2001;61(2):142-146.

33. Varga Z, Karpati I, Paragh G, Buris L, Kakuk G. Relative abundance of some free fatty acids in plasma of uremic patients: relationship between fatty acids, lipid parameters, and diseases. Nephron. 1997;77:417-421.

34. Reaven P, Parthasarathy S, Grasse BJ, Miller E, Almazan F, Mattson FH, Khoo JC, Steinberg D, Witztum JL. Feasibility of using an oleate-rich diet to reduce the susceptibility of low-density lipoprotein to oxidative modification in humans. Am J Clin Nutr. 1991;54:701-706.

35. Miettinen TA, Naukkarinen V, Huttunen JK, Mattila S, Kumlin T. Fatty-acid composition of serum lipids predicts myocardial infarction. $\mathrm{Br}$ Med J Clin Res Ed. 1982; 285:993-996.

36. Bønaa KH, Bjerve KS, Nordøy A. Habitual fish comsumption, plasma phospholipid fatty acids and serum lipids: the Troms $\varnothing$ study. Am J Clin Nutr. 1992;55:1126-1134.

37. Grimsgaard S, Bønaa KH, Bjerve KS. Fatty acid chain length and degree of unsaturation are inversely associated with serum triglycerides. Lipids. 2000;35:1185-1193.

38. Holman RT, Johnson SB, Bibus D, Spencer DC, Donadio JV. Essential fatty acid deficiency profiles in immunoglobulin A nephropathy. Am J Kidney Dis. 1994;23:648-654.

39. Avram M. Similarities between glomerular sclerosis in human renal biopsy specimens: a role for lipoprotein glomerulopathy. Am J Med. 1989;87:39N-41N.

40. Siscovick DS, Raghunathan TE, King I, et al. Dietary intake and cell membrane levels of long-chain $n-3$ polyunsaturated fatty acids and the risk of primary cardiac arrest. JAMA. 1995;274:1363-1367.

41. Komidori K, Kamada T, Yamashita T, Harada R, Otsuji Y, Hashimoto S, Chuman Y, Otsuji S. Erythrocyte membrane fluidity decreased in uremic hemodialyzed patients. Nephron. 1985;40:185-188.

42. Mills DE, Murphy M, Galley WR. Dietary fatty acids, membrane transport, and oxidative sensitivity in human erythrocytes. Lipids. 1995;30:657-663.

43. Peuchant E, Delmas-Beauvieux MC, Duborg L, Thomas MJ, Perromat A, Aparricio M, Clerc M, Combe C. Antioxidant effects of a supplemented very low protein diet in chronic renal failure. Free Radical Biol Med. 1997; 22:313-320.

44. Nishizawa Y, Shoji T, Ishimura E, Inaba M, Morii H. Paradox of risk factors for cardiovascular mortality in uremia: is a higher cholesterol level better for atherosclerosis in uremia? Am J Kidney Dis. 2001;38(4 Suppl 1): S4-S7.

45. Bjerve KS, Brubakk AM, Fougner KJ, Johnsen H, Midthjell K, Vik T. Omega-3 fatty acids: essential fatty acids with important biological effects and serum phospholipid fatty acids as markers of dietary omega-3 fatty acid intake. Am J Clin Nutr. 1993;57:801S-806S. 